\title{
PENGOLAHAN SAMPAH MEDIS JARUM RS. DR. SUTOMO SURABAYA DENGAN INCENERATOR MODIFIKASI
}

\author{
Oleh : Indah Nurhayati *) \& Siti Agustina Triastuti ${ }^{\star *}$ )
}

\begin{abstract}
Abstrak
Salah satu kendala dari pengolahan sampah medis dengan insenetaror adalah sampah logam seperti jarum suntik dan gelas seperti botol kaca tidak terbakar sempurna. Jarum suntik dan botol kaca memerlukan suhu pembakaran yang tinggi dan waktu yang lebih lama dibandingkan dengan pembakaran sampah medis yang lain. Penggunaan insenerator yang kurang optimum mempunyai beberapa kerugian, diantaranya: kerusakan alat, boros bahan bakar, tingginya residu pembakaran, timbul asap pembakaran, timbul bau tidak sedap, dan timbul partikulat yang menyebabkan pencemaran bagi lingkungan sekitar. Penelitian ini bertujuan untuk mengkaji pengaruh suhu dan waktu pembakaran terhadap efisiensi pembakaran, dan untuk mengetahui kondisi optimum pembakaran sampah medis jarum suntik dan plastik dengan insenerator modifikasi. Variabel dalam penelitian ini adalah suhu pembakaran yaitu $600^{\circ} \mathrm{C}, 800^{\circ} \mathrm{C}$ dan $1000^{\circ} \mathrm{C}$, dan waktu pembakaran yaitu : 5 menit, 10 menit, 15 menit dan 20 menit. Parameter penelitian in adalah efisiensi pembakaran, kualitas asap dan abu pembakaran. Data hasil penelitian dianalisis dengan menggunakan grafik. Hasil penelitian ini menunjukan bahwa semakin tinggi suhu pembakaran dan semakin lama waktu pembakaran menghasilkan efisiensi yang semakin tinggi, kualitas abu dan asap pembakaran juga semakin baik. Kondisi optimum untuk pembakaran sampah medis jarum suntik dan plastik dengan insenerator modifikasi tercapai pada suhu $1000^{\circ} \mathrm{C}$ dan lama pembakaran 15 menit.
\end{abstract}

Kata kunci : Insenerator, Sampah Medis, Jarum Suntik.

\section{PENDAHULUAN Latar Belakang}

Sampah dapat mencemari lingkungan penduduk di sekitar rumah sakit dan dapat menimbulkan masalah kesehatan. Hal ini dikarenakan dalam limbah rumah sakit dapat mengandung berbagai jasad renik penyebab penyakit pada manusia termasuk demam typoid, kholera, disentri dan hepatitis sehingga limbah harus diolah sebelum dibuang ke lingkungan (BAPEDAL, 1999). Sampah medis sangat membayahakan dan menimbulkan gangguan kesehatan bagi pengunjung dan petugas yang menangani sampah tersebut. Oleh karena itu sampah medis perlu dikelola dengan baik supaya aman dan tidak membahayakan manusia dan lingkungan sekitar. Salah satu cara pengolahan sampah medis adalah dengan cara dibakar menggunakan insenerator. Penanganan sampah medis di RSUD Dr.Soetomo Surabaya dilakukan dengan dibakar menggunakan insinerator. Penggunaan insenerator untuk pemusnahan sampah medis merupakan salah satu cara yang umum digunakan di rumah sakit karena tidak membutuhkan lahan yang luas dan praktis pengoperasiannya. Fungsi utama dari pengolahan sampah medis dengan insenerator adalah untuk memutus rantai penyebaran penyakit infeksius yang disebarkan oleh sampah medis. Salah satu kendala dari pengolahan sampah medis dengan insenetaror adalah tidak semua jenis sampah dapat dimusnahkan terutama sampah dari logam seperti jarum suntik dan gelas seperti botol kaca. Jarum suntik dan botol kaca memerlukan suhu pembakaran yang tinggi dan waktu yang lebih lama dibamdingkan dengan pembakaran sampah medis yang lain.

Penggunaan insenerator yang tidak optimum mempunyai beberapa kerugian, diantaranya: kerusakan alat, boros bahan bakar, tingginya residu pasca bakar, timbul asap pembakaran, timbul bau tidak sedap dan timbul partikulat yang menyebabkan pencemaran bagi lingkungan sekitar.

Suhu pada ruang bakar insenerator yang terlalu rendah menyebabkan pembakaran tidak sempurna dan residu yang tinggi, namun suhu yang tinggi membutuhkan bahan bakar yang banyak sehingga kurang efisien. waktu pembakaran yang singkat menyebabkan pembakaran kurang tuntasnya proses pembakaran, tetapi terlalu lama waktu pembakaran juga menyebabkan pemborosan bahan bakar. Untuk mendapatkan gambaran yang optimum dari suhu dan waktu pembakaran perlu adanya pengkajian yang mendalam tentang kedua hal tersebut. sehingga pengolahan sampah medis dengan incinerator lebih efisien. 
*) Dosen Teknik Lingkungan

**) Mahasiswa Teknik Lingkungan

Universitas PGRI Adi Buana Surabay

RSUD Dr. Sutomo Surabaya setiap harinya rata-rata menghasilkan sampah medis tajam $42,5 \mathrm{~kg}$. Penanganan sampah medis di RSUD Dr.Soetomo Surabaya dilakukan dengan insinerator. Salah satu faktor yang mempengaruhi pemusnahan sampah dengan insinerator adalah pengaturan suhu dan waktu pembakaran. RSUD Dr.Soetomo Surabaya mempunyai tiga insinerator dengan kapasitas seluruhnya $1200 \mathrm{~kg} / \mathrm{hari}$, dan ketiganya adalah buatan pabrik yang sudah teruji kualitasnya. Namun cara kerja pembakaran tiga insinerator tersebut adalah dengan memasukkan semua jenis sampah medis yang berupa sampah medis lunak dan sampah medis tajam digabung menjadi satu dalam pembakaran incinerator. Pembakaran sampah medis dengan insenerator di RSUD Dr Sutomo belum optimal, hal ini ditandai dengan dihasilkannya abu pembakaran masih terdapat botol-botol yang belum hancur bahkan terdapat bekas jarum yang masih utuh.

Residu hasil akhir pembakaran yang masih belum sempurna ini sering membahayakan petugas dan lingkungan. Untuk menangani permasalahan tersebut RSUD DR.Soetomo Surabaya membuat incinerator yang digunakan khusus untuk memusnahkan/membakar jarum.

Berdasarkan permasalahan diatas maka penulis tertarik untuk mengadakan penelitian tentang pengolahan sampah medis jarum dengan incinerator modifikasi di RSUD Dr.Soetomo Surabaya. Tujuan yang ingin dicapai dalam penelitian ini adalah untuk mengkaji pengaruh suhu dan waktu pembakaran terhadap efisiensi pembakaran, kualitas asap dan abu hasil pembakaran serta untuk mengetahui kondisi optimum pembakaran sampah medis jarum suntik dan plastik dengan insenerator modifikasi.

\section{TINJAUAN PUSTAKA Sampah Medis}

Sampah medis adalah benda di rumah sakit/unit pelayanan kesehatan yang sudah tidak digunakan lagi namun telah tercemar atau terkontaminasi dengan bahan berbahaya atau cairan tubuh manusia, misalnya kencing, darah, serum screet, ludah, lumbal, dll yang kemungkinan besar mengandung kumankuman penyakit yang dapat tersebut dapat berwujud cair atau padat. Sampah medis terdiri dari sampah infeksius, sampah patologi, sampah farmasi, sampah sitotoksis, sampah kimiawi, sampah radioaktif, sampah benda tajam dan sampah dengan kandungan logam berat yang tinggi. Sampah medis disebut juga dengan sampah infeksius.

Bentuk sampah medis padat yang biasanya dijumpai di rumah sakit atau unit pelayanan kesehatan lainnya antara lain :kapas bekas digunakan untuk tindakan pada pasien, spuit dan jarum suntik bekas setelah digunakan untuk tindakan pada pasien, botol infuse yang terkontaminasi dengan darah atau serum penderita, selang infuse yang terkontaminasi cairan tubuh, pembalut wanita yang sudah terpakai, alat/material lainnya yang sudah tidak digunakan lagi dan telah terkontaminasi atau mengandung cairan toksik dan jaringan tubuh penderita.

Bentuk sampah medis cair yang biasanya dijumpai di rumah sakit atau unit pelayanan kesehatan lainnya antara lain : sampah cair yang berasal dari septictank (WC), sampah cair yang berasal dari urinoir, kamar mandi pasien, darah bekas transfuse dan darah yang sudah terpakai, sampah cair yang berasal dari sisa pemeriksaan laborat, sampah cair yang berasal dari kamar otopsi, sampah cair yang berasal dari ruang spulhock, sampah cair yang berasal dari pencucian linen dan sampah cair yang bersal dari ruang operasi.

Sampah kimiawi dapat juga tercampur dengan cairan infeksius misalnya pengawet jaringan menggunakan formalin begitu pula sampah kimiawi yang dihasilkan dari laboratorium, karena cairan kimia sebagai larutan pereaksi. Pada kegiatan pendcucian film di ruang radiologi juga menghasilkan sampah kimia yang beresifat infeksius.

sampah jaringan tubuh manusia juga termasuk kategori sampah medis. Jaringan tubuh meliputi organ, anggota badan, darah dan cairan tubuh biasannya dihasilkan pada saat pembedahan atau autopsi. Jaringan tubuh yang tampak nyata seperti anggota badan dan placenta yang tidak memerlukan pengesahan penguburan hendaknya dikemas secara khusus, diberi label dan dibuang ke incinerator di bawah pengawasan petugas yang berwenang.

Cairan tubuh, terutama darah dan cairan yang terkontaminasi berat oleh darah harus diperlukan dengan hati-hati. Dalam jumlah kecil, dan bila mungkin dapat diencerkan sehingga dapat dibuang ke dalam system saluran pengolahan air sampah.

Kelompok sampah medis lainya adalah sampah citotoksik dan sampah farmasi. Sampah citotoksik adalah bahan yang terkontaminasi atau mungkin terkontaminasi dengan obat citotoksik selama peracikan, pengangkutan atau tindakan terapi citotoksik (Ditjen PPM dan PLP Depkes RI, 1995) 


\section{Insenerator}

Insenerasi adalah sebuah proses pembakaran yang memungkinkan materi yang mudah terbakar seperti halnya sampah organik mengalami pembakaran. Limbah dapat terurai dari senyawa organik menjadi senyawa sederhana seperti $\mathrm{CO} 2$ dan $\mathrm{H} 2 \mathrm{O}$. Hasil pembakaran berupa residu materi yang sulit terbakar dan abu serta gas/partikulat. Residu serta abu yang dihasilkan, dikeluarkan dari incinerator dan ditimbun dilahan. Sedangkan gas/ partikulat dikeluarkan melalui cerobong melalui sarana pengolah pencemar udara yang sesuai. Incenerator efektif terutama untuk buangan organik dalam bentuk padat, cair, gas, lumpur cair dan lumpur padat. Proses ini tidak biasa digunakan limbah organik seperti lumpur logam berat (heavy metal sludge) dan asam anorganik.

Pengolahan sampah dengan insenerasi dapat mengurangi volume dan massa serta mengurangi sifat berbahaya dari sampah tersebut jika sampah tersebut adalah sampah bahan berbahaya dan beracun. Faktor yang memegang peranan penting dalam insenerasi adalah temperatur pembakaran dan waktu pembakaran sampah tersebut.

Teknologi incenerasi merupakan cara pengolahan yang baik bagi materi yang mudah terbakar dan memiliki nilai kalor yang memadai. Sampah berbahaya yang patogenik, seperti sampah dari rumah sakit terutama untuk sampah medis yang berkatagori sampah infeksius, sangat baik ditangani dengan cara ini. Mikroorganisme pathogen dalam sampah infeksius dapat dimusnahkan di sebuah incinerator yang baik karena adanya panas yang tinggi. Waktu tinggal sampah serta temperatur operasi merupakan parameter tertentu dalam keberhasilan proses incenerasi sampah medis.

Kerja incinerator dipengaruhi oleh jumlah oksigen, proses pengadukan dan pencampuran dalam incinerator, suhu yang cukup untuk volatilisasi, dan waktu untuk terjadinya reaksi. Untuk menjaga kesempurnaan pembakaran di incinerator dan mencegah kerusakan pada dinding pembakar, maka gelas dan logam tidak ikut dibakar.

Penggunaan incinerator di rumah sakit harus memperhatikan ukuran, desain terkait dengan emisinya, penempatan lokasi yang berkaitan dengan jalur pengangkutan sampah dalam kompleks rumah sakit dan jalur pembuangan abu, dan sarana gedung untuk melindungi incinerator dari bahaya kebakaran. Faktor penting dalam proses incenerasi adalah a. Pengaturan suhu dalam incinerator. Pada suhu rendah sampah akan terbakar kurang sempurna sehingga akan menimbulkan asap, gas yang mencemari udara. Waktu pembakaran jika suhu belum cukup, pembakaran belum boleh dilakukan.

b. Pengaturan oksigen $\left(\mathrm{O}_{2}\right)$. Tanpa adanya suplay udara ke dalam incinerator, pembakaran akan berhenti.

c. Jumlah sampah yang akan dibakar harus disesuaikan dengan kapasitas incinerator dan frekuensi pembakaran.

Keuntungan dari pengolahan sampah dengan menggunakan insenerator antara lain, dapat mengurangi volume sampah, dapat membakar beberapa jenis sampah termasuk sampah medis toksik mrnjadi non toksik, infeksius menjadi non infeksius, lahan yang dibutuhkan relative tidak luas, pengoperasiannya tidak tergantung pada iklim, residu abu dapat digunakan untuk mengisi tanah yang rendah, yang mengandung bahanbahan organic dan bebas dari gangguan terhadap kesehatan dan lingkungan.

Kerugian dari pengolahan sampah dengan menggunakan insenerator antara lain tidak semua jenis sampah dapat dimusnahkan terutama sampah dari logam dan botol, dapat menimbulkan pencemaran udara bila tidak dilengkapi dengan pollution control, maka dalam incinerator perlu dilengkapi dengan udara berputar (cyclone) atau penghisap debu ( bag filter), modal awal sangat tinggi, biaya operasi relative tinggi, bukan merupakan metode pembuangan yang lengkap, sebab abu sisa proses pembakaran lainnya harus dibuang dengan cara lain. Penggunaan incinerator ternyata melahirkan masalah baru yaitu pencemaran udara oleh partikel dan logam berat yang melewati kadar ambang batas (Adiputra,2003)

Efisiensi pembakaran yang tinggi akan dapat dicapai bilamana sampah medis bakar pada kondisi- kondisi :

1. Jumlah oksigen yang cukup untuk terjadinya reaksi yang sempurna pada semua sampah.

2. Atomisasi dan volatilisasi, yaitu merubah sampah menjadi partikel-partikel yang sangat kecil dan gas (reaksi ini hanya terjadi pada tahap gas atau terhadap permukaan yang dapat langsung terkena oksigen

3. Proses pengadukan dan pencampuran dalam incinerator, sehingga membuat partikel sampah yang sangat kecil berhubungan dengan oksigen.

4. Suhu yang cukup untuk volatilisasi, akan menunjang kondisi pembakaran dapat terus berlangsung dan akan meningkat- 
kan terjadinya reaksi dalam waktu yang relative singkat

5. Cukup waktu untuk terjadinya reaksi. Lama waktu yang dipertahankan adalah waktu yang digunakan sampah gas berada dalam kamar pembakaran

Kondisi optimum juga tergantung pada jenis dan jumlah sampah yang akan diincenerasikan, keberadaan debu dan gas yang minim sekali, dan sampah yang mengandung bahan kimia berbahaya, terutama sampah farmasi tidak boleh masuk ke incinerator sampah medis.

\section{METODE PENELITIAN \\ Lokasi Penelitian}

Penelitian ini adalah penelitian eksperimen dengan rancangan penelitian seperti digambarkan dalam gambar 1. Lokasi penelitian di RSUD Dr. Soetomo Surabaya.

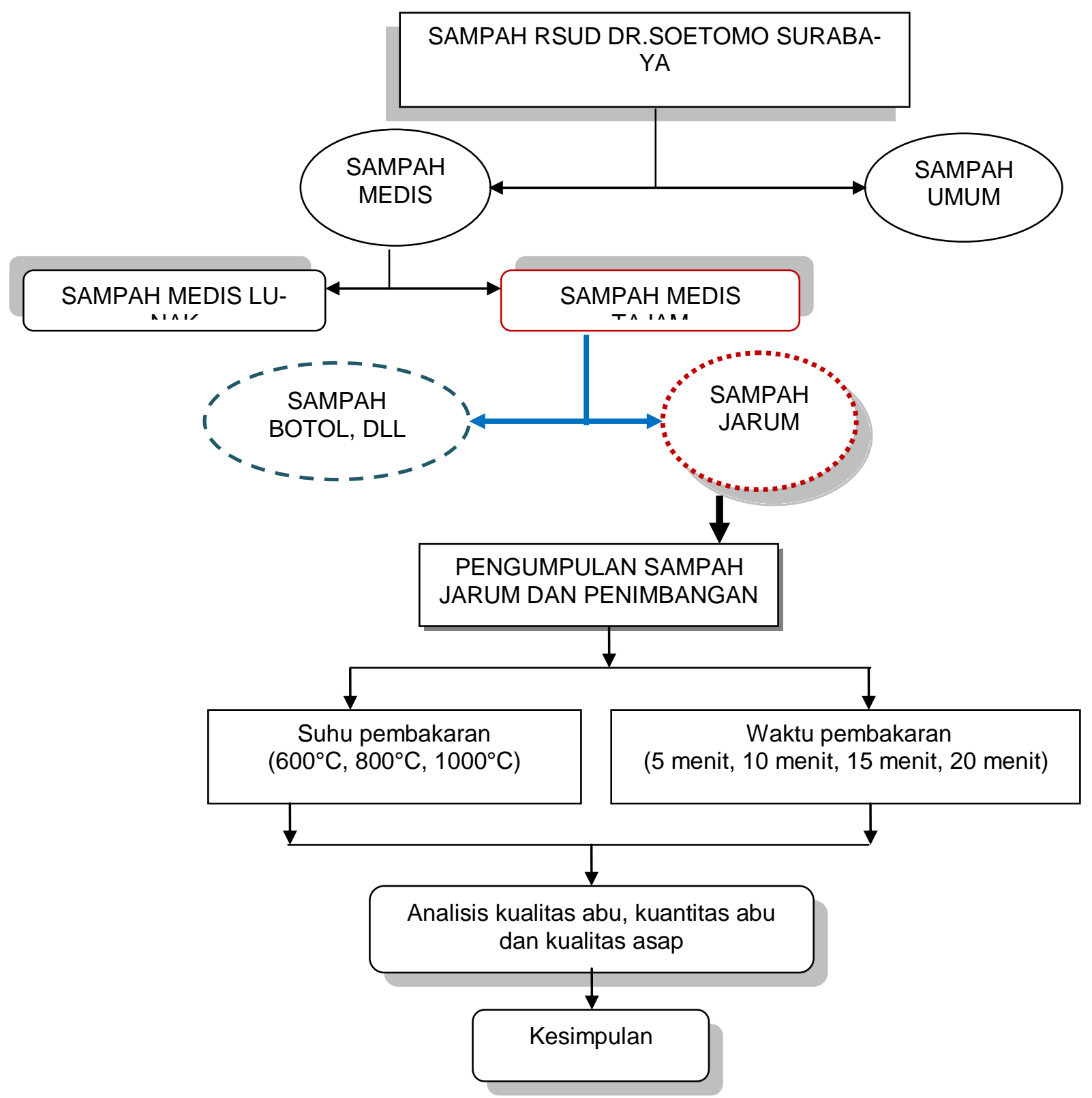

Gambar 1. Rancangan Penelitian

\section{Variabel}

Variable bebas dalam penelitian ini adalah suhu pembakaran yaitu : $600^{\circ} \mathrm{C}, 800^{\circ} \mathrm{C}$ dan $1000^{\circ} \mathrm{C}$, dan waktu pembakaran yaitu : 5 menit, 10 menit, 15 menit dan 20 menit. Parameter pada penelitian ini adalah kuantitas abu, kualitas abu dan kualitas asap pembakaran. Kuantitas abu pembakaran ditentukan dengan cara menimbang abu pembakaran. kuantiats abu pembakaran dianalisis untuk mengetahui 
besarnya efisiensi. Kualitas abu hasil pembakaran ditentukan dengan cara mengamati abu pembakaran sudah terbakar sempurna atau masih ada material yang belum sempurna terbakar. Kualitas asap ditentukan dengan cara mengamati warna asap pada saat pembakaran.

\section{Materi Penelitian}

Alat dan bahan yang digunakan pada penelitian ini adalah incinerator hasil modifikasi dari RSUD Dr.Soetomo Surabaya dengan spesifikasi : ukuran $100 \times 100 \times 100 \mathrm{~cm}$, ruang bakar $60 \times 15 \times 15 \mathrm{~cm}$, bahan bakar solar, temperature $\max 1200^{\circ} \mathrm{C}$, lapisan batu tahan api ( Castabel C16), patient control digital dan kapasitas $5 \mathrm{~kg}$. Peralatan penunjang lain adalah thermometer, cepuk tahan api, tangkai pengait, timbangan, stop wach.

Sampel yang digunakan adalah sampah medis jarum dari RSUD Dr. Sutomo Surabaya.

\section{Tahapan Penelitian}

Preparasi sampel

1. Pemisahan sampah medis dan sampah umum.

2. Sampah medis dipilah antara sampah lunak dengan sampah tajam

3. Sampah medis jarum sebelum dimasukkan ke tempat sampah medis dipisahkan dengan plastiknya dengan cara jarum dipotong dengan alat pemotong jarum.

4. Sampah medis jarum ditimbang 500 gram, dimasukan ke dalam cepuk pembakaran. dan siap dibakar dengan incinerator.

Pembakaran sampah medis jarum dengan incinerator modifikasi
1. Temperatur dan waktu pembakaran diseting sesuai dengan yang dikehendaki yaitu waktu pembakaran selama 5 menit, 10 menit, 15 menit dan 20 menit dan suhu pembakaran $600^{\circ} \mathrm{C}, 800^{\circ} \mathrm{C}, 1000^{\circ} \mathrm{C}$.

2. Sumber listrik dihidupkan

3. Power dan pembakaran dihidupkan

4. Jika temperatur sudah sesuai dengan yang dikehendaki, sampah medis jarum yang sudah dimasukkan dalam cepuk dimasukkan dengan menggunakan alat dan pintu ditutup.

5. Pembakaran akan mati secara otomatis sesuai waktu yang telah diseting.

6. Setelah dingin cepuk dikeluarkan dari tungku dengan menggunakan alat.

7. Abu pembakaran ditimbang dengan menggunakan neraca analitik dan dihitung efisiensinya.

8. Abu pembakaran diamati masih adakah material yang belum terbakar sempurna.

9. Pada saat pembakaran asap hasil pemabakaran diamati secara langsung.

\section{Analisis Data}

Data-data yang terkumpul disajikan dalam bentuk tabel, grafik

\section{HASIL DAN PEMBAHASAN}

Berat residu pembakaran sampah medis jarum menggunakan insenerator modifikasi pada suhu ruang bakar $600^{\circ} \mathrm{C}, 800^{\circ} \mathrm{C}$, $1000^{\circ} \mathrm{C}$ dan waktu pembakaran 5 menit, 10 menit, 15 menit dan 20 menit dengan berat sampah medis masing-masing 500 gram disajikan dalam $\quad$ Tabel 1.

Tabel 1.Residu Pembakaran Sampah Medis Jarum dengan Insenerator Modifikasi

\begin{tabular}{clllll}
\hline \multirow{2}{*}{ Waktu } & Pengulangan & \multicolumn{3}{l}{$\begin{array}{l}\text { Berat sampah } \\
\text { yang dibakar }\end{array}$} & \multicolumn{3}{l}{$\begin{array}{l}\text { Berat Residu }(\mathrm{kg}) \\
\text { Pada Suhu Pembakaran }\end{array}$} \\
\cline { 3 - 6 } & & $(\mathrm{Kg})$ & $600^{\circ} \mathrm{C}$ & $800^{\circ} \mathrm{C}$ & $1000^{\circ} \mathrm{C}$ \\
\hline 5 menit & 1 & 0,5 & 0,45 & 0,4 & 0,3 \\
& 2 & 0,5 & 0,43 & 0,41 & 0,3 \\
& 3 & 0,5 & 0,45 & 0,4 & 0,35 \\
& 4 & 0,5 & 0,43 & 0,4 & 0,3 \\
Rerata & & $\mathbf{0 , 5}$ & $\mathbf{0 , 4 4}$ & $\mathbf{0 , 4 0 2 5}$ & $\mathbf{0 , 3 1 2 5}$ \\
10 menit & 1 & 0,5 & 0,4 & 0,4 & 0,25 \\
& 2 & 0,5 & 0,41 & 0,35 & 0,2 \\
& 3 & 0,5 & 0,4 & 0,4 & 0,25 \\
& 4 & 0,5 & 0,4 & 0,35 & 0,25 \\
Rerata & & $\mathbf{0 , 5}$ & $\mathbf{0 , 4 0 2 5}$ & $\mathbf{0 , 3 7 5}$ & $\mathbf{0 , 2 3 7 5}$ \\
15 menit & 1 & 0,5 & 0,4 & 0,3 & 0,1 \\
& 2 & 0,5 & 0,35 & 0,3 & 0,1
\end{tabular}




\begin{tabular}{clllll}
\hline \multirow{2}{*}{ Waktu } & Pengulangan & $\begin{array}{l}\text { Berat sampah } \\
\text { yang dibakar }\end{array}$ & \multicolumn{3}{l}{$\begin{array}{l}\text { Berat Residu }(\mathrm{kg}) \\
\text { Pada Suhu Pembakaran }\end{array}$} \\
\cline { 2 - 6 } & & $(\mathrm{Kg})$ & $600^{\circ} \mathrm{C}$ & $800^{\circ} \mathrm{C}$ & $1000^{\circ} \mathrm{C}$ \\
\hline \multirow{4}{*}{ Rerata } & 3 & 0,5 & 0,4 & 0,3 & 0,15 \\
& 4 & 0,5 & 0,35 & 0,3 & 0,15 \\
20 menit & 1 & $\mathbf{0 , 5}$ & $\mathbf{0 , 3 7 5}$ & $\mathbf{0 , 3}$ & $\mathbf{0 , 1 2 5}$ \\
& 2 & 0,5 & 0,3 & 0,25 & 0,025 \\
& 3 & 0,5 & 0,3 & 0,25 & 0,025 \\
& 4 & 0,5 & 0,3 & 0,25 & 0,02 \\
Rerata & & 0,5 & 0,3 & 0,25 & 0,025 \\
\hline
\end{tabular}

Kualitas abu hasil pembakaran diamati secara langsung dan dikelompokan menjadi tiga kategori, yaitu : kategori A jika kualitas abu menunjukan plastic dan jarum sudah terbakar sempurna, kategori B, jika plastik sudah terbakar sempurna tetapi jarum belum terbakar sempurna, kategori $C$, jika plastik dan jarum belum terbakar sempurna.
Kualitas abu pembakaran pada suhu suhu ruang bakar $600^{\circ} \mathrm{C}, 800^{\circ} \mathrm{C}, 1000^{\circ} \mathrm{C}$ dan waktu pembakaran 5 menit, 10 menit, 15 menit dan 20 menit dengan berat sampah medis masing-masing 500 gram disajikan dalam Tabel 2.

Tabel 2.Kualitas Abu Pembakaran Sampah medis jarum dengan Insenerator Modifikasi

\begin{tabular}{|c|c|c|c|c|c|}
\hline \multirow[t]{2}{*}{ Waktu } & \multirow[t]{2}{*}{ Pengulangan } & \multirow{2}{*}{$\begin{array}{l}\text { Berat sampah } \\
\text { yang dibakar } \\
(\mathrm{Kg}) \\
\end{array}$} & \multicolumn{3}{|c|}{$\begin{array}{l}\text { Kategori Kuaitas Abu } \\
\text { Pada Suhu Pembakaran }\end{array}$} \\
\hline & & & $600^{\circ} \mathrm{C}$ & $800^{\circ} \mathrm{C}$ & $1000^{\circ} \mathrm{C}$ \\
\hline \multirow[t]{4}{*}{5 menit } & 1 & 0,5 & C & $\mathrm{C}$ & $\mathrm{B}$ \\
\hline & 2 & 0,5 & C & C & B \\
\hline & 3 & 0,5 & C & $\mathrm{C}$ & B \\
\hline & 4 & 0,5 & C & C & B \\
\hline \multirow[t]{4}{*}{10 menit } & 1 & 0,5 & $\mathrm{C}$ & C & B \\
\hline & 2 & 0,5 & C & C & B \\
\hline & 3 & 0,5 & C & C & B \\
\hline & 4 & 0,5 & C & C & B \\
\hline \multirow[t]{4}{*}{15 menit } & 1 & 0,5 & C & $\mathrm{B}$ & $A$ \\
\hline & 2 & 0,5 & C & $B$ & $A$ \\
\hline & 3 & 0,5 & C & B & $A$ \\
\hline & 4 & 0,5 & C & B & $A$ \\
\hline \multirow[t]{4}{*}{20 menit } & 1 & 0,5 & B & B & $A$ \\
\hline & 2 & 0,5 & B & $B$ & $A$ \\
\hline & 3 & 0,5 & B & B & $A$ \\
\hline & 4 & 0,5 & $\mathrm{~B}$ & $\mathrm{~B}$ & A \\
\hline
\end{tabular}

Keterangan

A : plastik dan jarum terbakar sempurna

B : plastik terbakar sempurna, jarum belum terbakar sempurna

C : plastik dan jarum belum sempurna terbakar Kualitas asap hasil pembakaran sampah jarum dengan insenerator modifikasi pada suhu ruang bakar $600^{\circ} \mathrm{C}, 800^{\circ} \mathrm{C}, 1000^{\circ} \mathrm{C}$ dan waktu pembakaran 5 menit, 10 menit, 15 menit dan 20 menit dengan berat sampah medis masing-masing 500 gram disajikan dalam Tabel 3. Kualitas asap hasil pembakaran dikelompokan dalam dua kategori, yaitu kategori $P$, jika asap 
pembakaran berwarna putih, dan kategori

kecoklatan.

$P$, jika asap pembakaran berwarna putih

Tabel 3.Kualitas Asap Pembakaran Sampah Medis Jarum dengan Insenerator Modifikasi

\begin{tabular}{|c|c|c|c|c|c|}
\hline \multirow{2}{*}{ Waktu } & \multirow{2}{*}{ Pengulangan } & \multirow{2}{*}{$\begin{array}{l}\text { Berat sampah yang } \\
\text { dibakar } \\
(\mathrm{Kg})\end{array}$} & $\begin{array}{l}\text { Kuaitas } \\
\text { karan }\end{array}$ & \multicolumn{2}{|c|}{ Pada Suhu Pemba- } \\
\hline & & & $600^{\circ} \mathrm{C}$ & $800^{\circ} \mathrm{C}$ & $1000^{\circ} \mathrm{C}$ \\
\hline \multirow[t]{4}{*}{5 menit } & 1 & 0,5 & $c ; p$ & C & C \\
\hline & 2 & 0,5 & $c ; p$ & C & C \\
\hline & 3 & 0,5 & $c ; p$ & C & C \\
\hline & 4 & 0,5 & $c ; p$ & C & C \\
\hline \multirow[t]{4}{*}{10 menit } & 1 & 0,5 & $c ; p$ & C & C \\
\hline & 2 & 0,5 & $c ; p$ & C & C \\
\hline & 3 & 0,5 & $c ; p$ & C & C \\
\hline & 4 & 0,5 & $c ; p$ & C & C \\
\hline \multirow[t]{4}{*}{15 menit } & 1 & 0,5 & $c ; p$ & C & $p$ \\
\hline & 2 & 0,5 & $c ; p$ & C & $p$ \\
\hline & 3 & 0,5 & $c ; p$ & C & $\mathrm{p}$ \\
\hline & 4 & 0,5 & $c ; p$ & C & $p$ \\
\hline \multirow[t]{4}{*}{20 menit } & 1 & 0,5 & $c ; p$ & C & $p$ \\
\hline & 2 & 0,5 & $c ; p$ & C & $p$ \\
\hline & 3 & 0,5 & $c ; p$ & C & $\mathrm{p}$ \\
\hline & 4 & 0,5 & $c ; p$ & C & $p$ \\
\hline
\end{tabular}

Keterangan $\quad$ C : asap berwarna coklat keputihan

$\mathrm{P}$ : asap berwarna putih

\section{Pengaruh Waktu Pembakaran Terhadap} Efisiensi Pembakaran

Untuk mengetahui optimasi pembakaran salah satunya adalah dilihat dari tingkat efisiensinya. Dari hasil penelitian seperti yang tersaji dalam tabel 1, kemudian analisis efisiensi rata-ratanya untuk setiap lamanya waktu pembakaran. Efisiensi pembakaran rata-rata jarum suntik pada suhu ruang bakar $600^{\circ} \mathrm{C}, 800^{\circ} \mathrm{C}, 1000^{\circ} \mathrm{C}$ dan waktu pembakaran 5 menit, 10 menit, 15 menit dan 20 menit disajikan dalam tabel 4 . Dari tabel 4 dapat dilihat bahwa efisiensi tertinggi sebesar 95,5\% diperoleh pada suhu pembakaran $1000^{\circ} \mathrm{C}$ dengan lama pembakaran 20 menit.

Tabel 4. Efisiensi Rata-Rata Pembakaran Jarum Suntik

\begin{tabular}{llll}
\hline \multirow{2}{*}{ waktu } & \multicolumn{3}{l}{$\begin{array}{l}\text { efisiensi pembakaran rata-rata } \\
\text { pada suhu ruang bakar }(\%)\end{array}$} \\
\cline { 2 - 4 } & $600^{\circ} \mathrm{C}$ & $800^{\circ} \mathrm{C}$ & $1000^{\circ} \mathrm{C}$ \\
\hline 5 menit & 12 & 19,5 & 37,5 \\
10 menit & 19,5 & 25 & 52,5 \\
15 menit & 25 & 40 & 75 \\
20 menit & 40 & 50 & 95,5 \\
\hline
\end{tabular}

Pengaruh waktu pembakaran terhadap efisiensi pembakaran sampah medis jarum disajikan dalam gambar 2 .

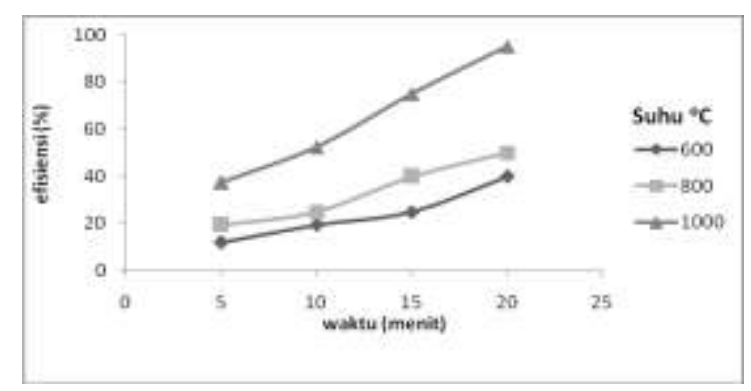

\section{Gambar 2. Pengaruh Waktu Pembakaran Terhadap Efisiensi Pembakaran}

Dari gambar 2 dapat dilihat bahwa waktu pembakaran berpengaruh terhadap efisiensi pembakaran, semakin lama waktu pembakaran sampah medis jarum semakin tinggi efisiensinya untuk suhu pembakaran $600^{\circ} \mathrm{C}, 800^{\circ} \mathrm{C}, 1000^{\circ} \mathrm{C}$. Keadaan ini menunjukan bahwa semakin lama waktu pembakaran semakin lama waktu untuk terjadinya reaksi pembakaran, sehingga semakin sempurna pembakarannya. semakin lama pembakaran 
berat residu semakin sedikit (Handayani, 2008)

\section{Pengaruh Suhu Pembakaran Terhadap Efisiensi Pembakaran}

Hasil analisis pengaruh suhu pembakaran terhadap efisiensi pembakaran disajikan dalam gambar 3. Dari gambar 3 dapat dilihat bahwa suhu pembakaran berpengaruh terhadap efisiensi pembakaran, semakin tinggi suhu pembakaran semakin tinggi efisiensinya, pada suhu pembakaran 5 menit, 10 menit, 15 menit dan 20 menit. Hal ini disebabkan pada suhu tinggi dan waktu pembakaran yang lama menyebabkan tercukupinya oksigen sebagai syarat utama dalam pembakaran dan akan meningkatkan terjadinya reaksi.

\section{Gambar 3. Pengaruh Suhu Pembakaran Sampah Medis Jarum Terhadap Efisiensi Pembakaran}

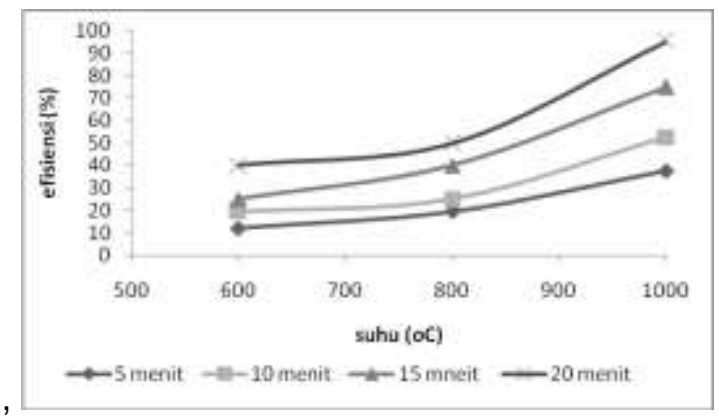

\section{Pengaruh Suhu Dan Waktu Pembakaran Terhadap Kualitas Asap dan Residu Hasil Pembakaran}

Optimasi pembakaran selain dilihat dari efisiensi pembakaran juga dilihat dari kualitas abu dan kualitas asap pembakaran. Kualitas abu hasil pembakaran dapat dilihat dari masih ada tidaknya material yang belum terbakar sempurna. Kualitas asap dilihat dari warna asap pembakaran, semakin putih asap pembakaran semakin sempurna proses pembakaran.

Dari tabel 2 dan 3 dapat dilihat bahwa waktu dan suhu pembakaran berpengaruh terhadap kualitas asap dan abu hasil pembakaran. Semakin tinggi suhu dan waktu pembakaran semakin baik kualitas asap dan abu pembakaran. Pada suhu pembakaran $1000^{\circ} \mathrm{C}$ dengan lama waktu pembakaran 15 menit dan 20 menit menghasilkan abu hasil pembakaran dengan kualitas yang baik karena semua material sudah terbakar sempurna dan asap pembakaran juga kualitasnya baik karena sudah berwarna putih. Keadaan ini disebabkan sudah terjadi pembakaran yang sempurna sehingga semua material jarum dan plastik sudah terbakar.

Berdasarkan efisiensi hasil pembakaran, kualitas abu dan asap hasil pembakaran maka optimasi pembakaran sampah medis jarum dengan insenerator modifikasi di RS DR. Sutomo Surabaya terjadi pada suhu $1000^{\circ} \mathrm{C}$ dengan lama pembakaran 15 menit.

\section{SIMPULAN}

Dari penelitian tentang kajian kinerja optimasi insenerator modifikasi untuk pembakaran sampah medis jarum suntik di RS DR. Sutomo Surabaya dapat disimpulkan bahwa, semakin tinggi suhu dari $600^{\circ} \mathrm{C}$ sampai 1000 ${ }^{\circ} \mathrm{C}$ dan semakin lama waktu pembakaran semakin besar efisiensinya dan kualitas abu dan asapnya juga semakin baik. Kondisi optimal untuk pembakaran sampah medis jarum tercapai pada suhu $1000{ }^{\circ} \mathrm{C}$ dan lama pembakaran $20 \quad$ menit.

\section{DAFTAR PUSTAKA}

Adiputra, Nyoman. 2003. Limbah Rumah Sakit Dan Masalahnya. Short Course on Environmental Pollution Control and Management Kerjasama PSLH UNUD dengan PT Amythas Experts \& Associates, Denpasar, 25 Agustus - 19 September.

BAPEDAL. 1999. Peraturan tentang Pengendalian Dampak Lingkungan.

Dirjen PPM \& PLP.1992 . Pedoman Sanitasi Rumah Sakit di Indoneia. Depkes.RI, Jakarta.

Dirjen PPM \& PLP , 1992. Pedoman Teknis Pengelolaan Limbah Klinis Dan Desinfektan \& Sterilisasi di Rumah Sakit. Depkes.RI,Jakarta.

Green, Alex E.S, 1992. Medical Waste Inceneration And Pollution Prevention.Van Nostrand Reinhald, New York, USA. 
Handayani, Wuri Diah .2008. Efisiensi Pembakaran Sampah Medis Dengan Insenerator Rumah Sakit Umum Kabupaten Sidoarjo, Buletin human Media, Vol 03, No. 04.hal 21 - 27.

Purwoto, setyo. 2008. Kndisi Optimal Insenerator Untuk Pembakaran Sampah Medis. Jurnal IImiah Sains dan IImu Pendidikan Wahana Volume 51 Nomor 01 Halaman 27-37.

Rr Widarizti Y \& Azay Ragsul, (2008). Pengolahan sampah Medis dengan incinerator di RS Dr.Soetomo Surabaya . Laporan Kerja Praktek, Jurusan Teknik Lingkungan . FTSP-ITS, Surabaya.

Saruju Didik, 1985. Pengelolaan sampah. Akademik Penilik Kesehatan Teknologi sanitasi, Surabaya. 